\title{
Study on Various Activities in Men and Women Self Help Groups in Shivamogga District, India
}

\author{
V. Chinmayi ${ }^{1 *}$ and Basavaraj Beerannavar ${ }^{2}$ \\ ${ }^{1}$ Department of Agricultural Extension, UAS, Raichur-584104, Karnataka, India \\ ${ }^{2}$ Department of Agricultural Extension, UAHS, Shivamogga, Karnataka, India \\ *Corresponding author
}

Keywords

Self help groups, constraints, Various activities

Article Info

Accepted:

12 March 2021

Available Online:

10 April 2021
The study was undertaken to find out the various activities undertaken and constraints and suggestion given by men and women SHGs in the shivamogga district of Karnataka. 150 respondents representing 30 SHGs formed the sample size and the data were collected. The study revealed that the 100 and 69.33 per cent of men SHG members undertook financial transaction and agriculture activities individually, in case of collective activities 46.67 per cent men SHG members took agriculture activities. Hundred per cent of women SHG members undertook financial transaction as individual activity. 26.67 per cent of income generation activities were undertaken by women collectively. Major constraint in both men and women SHGs was lack of technical guidance (42.67\%). Majority of the respondents $(80 \%)$ suggested that training programmes conducted based on their needs followed by 73.33 per cent members suggested to increase the loan and subsidy amount.

\section{Introduction}

India being a democratic country with welfare orientation has recognized that the best way to tackle poverty and to enable the community to improve its quality of life through social mobilization of poor into self help groups (SHGs). These are informal groups where members come together towards collective action for a common cause. It promotes qualities of as fellow-feeling, co-operation, cordiality, sympathy, understanding, leadership etc. among members. Entrepreneurial attributes are the qualitative improvements among in the members of SHG after adopting income generating activities. In India the concept of SHGs can be traced back to the Gandhian Grama Swaraj movement. It 
is mainly concerned with the poor and it is informal group of the people and for the people. The first effort in India was taken up by National Bank of Agriculture and Rural Development (NABARD) in 1986-87 when it supported and funded an action research project on "Saving and credit management of self help groups" of Mysore Resettlement and Development Agency (MYRADA). In 199192 NABARD launched a pilot project to provide micro credit by linking SHGs with bank. In 1999, Reserve Bank of India (RBI) setup a microcredit cell to make it easier to micro-credit providers to pursue institutional development process. Due to widening in the ratio of extension worker and farmers, more attention was given to group and mass contact method than individual approaches. The group based development efforts are coming up in a big way across the country in the recent years. In Karnataka State majority of the women SHGs were formed under the "Stree Shakti" and Swa-Shakti" programmes of the Government. Non-Government Organisations (NGOs) were also undertaken more and more efforts on formation of groups. Men also started forming in line with women SHGs groups to carry out agriculture activities, watershed programmes, sharing of agricultural equipments and marketing apart from financial activities. Both the State and Central Governments are giving due importance for the promotion and establishment of SHGs for addressing developmental issues.

The gender based SHGs have been doing several activities of their choice looking into the need of the situation and profitability. The common activities under taken were savings, training activities for members, loan repayment, book keeping and documentation, participation level, regular meetings, social activities etc. Keeping the above points in view the present study makes an attempt to understand the various activities undertaken and the constraints faced by members and their suggestions to improve the performance of SHGs priority given by members of SHGs.

\section{Objectives}

To understand the various activities undertaken and priority given by members of men and women SHGs.

To identify the constraints faced by members and their suggestions to improve the performance of SHGs.

\section{Materials and Methods}

Ex- post facto research design was followed for carrying out the study. Out of 30 districts in Karnataka, Shivamogga district was purposively selected as it is one of the front running districts in the SHG programme in Karnataka. Among seven taluks of Shivamogga district, three taluks viz., Shivamogga, Shikaripura and Hosanagar were purposively selected based on availability of highest number of both men and women SHGs. From these three taluks, five villages from each taluks were purposively selected, based on availability and functioning of both men and women SHGs. From each of 30 SHGs, five respondents were selected on the basis of their availability at the time of interview. The Groups which have completed minimum three years of function were selected for the study. The total sample size of the study was 150. Various activities like Financial transaction activities refer to SHG activities like savings, loans availed and repayment of loans by the members, Agriculture activities/farm activities it refers to the various farm activities taken by men and women SHGs and its members in order to improve in their production and also to increase their income level, Income generating activities it refers to the various activities taken up by men and women SHGs and its members in order to improve their standard of 
living, Social activities it refers to the various social activities taken up by men and women SHGs and its members in order to improve their village conditions and also to help others. The required data was collected directly from the respondents. It was expressed in frequency and percentage and Priority given by the members Priority under each level was adjudged by seeing percentage of members involved in the various activities.

\section{Results and Discussion}

\section{Various activities undertaken by Men SHG members}

It is evident from the results of Table 1 that, 100 and 69.33 per cent of men SHG members undertook financial transaction and agriculture activities individually. Only 20 per cent of the individual men respondents undertook income generating activities. In case of collective activities 46.67 per cent men SHG members took agriculture activities, followed by social activities (26.67\%) and income generation activities (13.33\%).

The data in Table 1 revealed that, 69.33 per cent men members involved in agriculture activities individually and 46.67 per cent of men members involved in agriculture activities collectively as these members got inherited land from their forefathers. The possible reason for under taking agriculture activities individually was due to majority of the members belongs to agriculture families. These members formed the groups with the intention of getting benefits to their agricultural activities. The groups promoted by Non Government Organizations namely SKDRDP are involved in collective labour sharing for agriculture activity. The men groups promoted by Chaitanya rural development society are involved in watershed development activities. Therefore, men members had given more priority to agricultural activities. Only 20 per cent of the men members undertaken income generation activities individually and 13.33 per cent collectively. As these members are having marginal land holding and the income from agriculture was not sufficient which motivated them for undertaking income generation activities.

Twenty men members (26.67\%) were collectively involved in social activities like general cleaning of the village, eradication of alcoholism, encouraging primary education and celebration of national festivals as social services. The findings are in line with Raghuprasad et al., (2004)

\section{Various activities undertaken by Women SHG members}

Hundred per cent of women SHG members undertook financial transaction as individual activity followed by 50.67 per cent income generation activities and 13.33 per cent agricultural activities. In women SHGs, 26.67 per cent of income generation activities were undertaken by women collectively. Only 17.33 per cent and 6.67 per cent collective activities related to agriculture and social service (Table 2).

The results presented in Table 2 shows that slightly more than half $(50.67 \%)$ of the women SHG members were involved in income generation activities individually and 20 respondents $(26.67 \%)$ collectively. This might be due to their personal interest, to reduce the dependence on their husbands and to earn money in their leisure time at home. Individual activities are better than group activities where there may not be coordination in the group to perform these activities.

The collective activities like crafting and rotti making were practiced by 20 respondents 
because of the familiarity of the women with these activities complemented by the easily mastered skills involved and the remunerative nature of the jobs.

Only 13.33 per cent women members are involved in agricultural activities as agriculture labours along with production of vermi compost and mushroom cultivation as individual activities due to possession of lesser land holding. Thirteen (17.33\%) women members were practicing sharing of labours for agriculture activities collectively to overcome labour problems. These members belong to agricultural families. The findings are in line with Bharathi (2005) and Devalatha (2005).

\section{Constraints experienced by SHG members}

Table 3 depicts the lack of technical guidance $(42.67 \%)$ as major constraint in both men and women SHGs. Lack of training and skill development facility (38.67\%), insufficient availability of loan (17.33\%), inadequate availability of raw materials for IGAs (16\%), there is no proper market for the products $(10.67 \%)$. The table also showed some other constraints faced by men SHGs like less repayment period $(5.34 \%)$, lack of time in participation in SHG due to other house hold activity (4\%), high rate of interest (2.67\%), lack of timely availability of loan from the SHG and dominance of few members in taking decision $(1.33 \%)$ were consider as constraints by men SHG members.

A glance at table 3 showed that among all the constraints experienced by women SHG members, lack of technical guidance (36\%), inadequate availability of raw materials for IGAs $(30.67 \%)$, lack of training and skill development facility (29.33\%), high rate of interest $(21.33 \%)$, less repayment period
(16\%). The moderate constraints expressed by Women men SHG members were, insufficient availability of loan (13.33\%), lack of timely availability of loan from the SHG (9.33\%), there is no proper market for the products and others like lack of co-ordination and dominance in taking decisions $(2.67 \%)$, and zero per cent of members facing lack of time in participation in SHG due to other house hold activities.

From the above description shows that, women SHG members giving more priority to income generating activities.

The Table 3 shows the various constraints faced by both the men and women SHG members. Lack of technical guidance $(42.67 \%)$ and $(36 \%)$ was the major constraint faced by both men and women members' respectively. This was followed by lack of training and skill development facility. This was due to lack of technical competence of the NGO staff to impart technical guidance to members. They are more competent on group dynamics than technical knowledge. Insufficient availability of loan was the third major constraint in men SHGs and sixth constraint in case of women SHGs. This is mainly because of the nature of micro finance (small loan) and group members have to wait for the group fund to grow to a larger extent and later they can get sufficient amount from the group. Inadequate availability of raw materials for Income generation activities was the second and fourth constraint in case of women and men SHGs respectively. This is due to the members carried out activity at their own premises, which was not so spacious and also they have to get raw materials from nearby towns which is the problem for them.

The findings are in line with Sangappa and Narasimha (2012). 
Table.1

\begin{tabular}{|c|c|c|c|c|c|}
\hline \multicolumn{2}{|c|}{ Sl. } & Activities & \multicolumn{2}{c|}{ Individually } & \multicolumn{2}{c|}{ Collectively } \\
\cline { 3 - 6 } No. & & Frequency & Percentage & Frequency & Percentage \\
\hline $\mathbf{1}$ & Financial transaction & 75 & 100 & - & - \\
\hline $\mathbf{2}$ & Agriculture activities & 52 & 69.33 & 35 & 46.67 \\
\hline $\mathbf{3}$ & $\begin{array}{c}\text { Income generating } \\
\text { activities }\end{array}$ & 15 & 20 & 10 & 13.33 \\
\hline $\mathbf{4}$ & Social activities & - & - & 20 & 26.67 \\
\hline
\end{tabular}

Table.2

\begin{tabular}{|c|c|c|c|c|c|}
\hline SI. & \multirow{2}{*}{ Activities } & \multicolumn{2}{|c|}{ Individually } & \multicolumn{2}{c|}{ Collectively } \\
\cline { 3 - 6 } No. & Frequency & Percentage & Frequency & Percentage \\
\hline $\mathbf{1}$ & Financial transaction & 75 & 100 & - & - \\
\hline $\mathbf{2}$ & Agriculture activities & 10 & 13.33 & 13 & 17.33 \\
\hline $\mathbf{3}$ & $\begin{array}{c}\text { Income generating } \\
\text { activities }\end{array}$ & 38 & 50.67 & 20 & 26.67 \\
\hline $\mathbf{4}$ & Social activities & - & - & 5 & 6.67 \\
\hline
\end{tabular}

Table.3

\begin{tabular}{|c|c|c|c|c|c|}
\hline \multirow{2}{*}{$\begin{array}{c}\text { Sl. } \\
\text { No }\end{array}$} & Items & \multicolumn{2}{|c|}{$\begin{array}{c}\text { Men SHG } \\
\text { members }\end{array}$} & \multicolumn{2}{c|}{$\begin{array}{c}\text { Women SHG } \\
\text { members }\end{array}$} \\
\cline { 3 - 6 } & & $\mathbf{F}$ & $\mathbf{\%}$ & $\mathbf{F}$ & $\%$ \\
\hline $\mathbf{1}$ & Lack of time in participation in SHG due to other house & 3 & 4 & 0 & 0 \\
\hline $\mathbf{2}$ & hold activity & 1 & 1.33 & 7 & 9.33 \\
\hline $\mathbf{3}$ & Lack of timely availability of loan from the SHG & 2 & 2.67 & 16 & 21.33 \\
\hline $\mathbf{4}$ & High rate of interest & 13 & 17.33 & 10 & 13.33 \\
\hline $\mathbf{5}$ & Insufficient availability of loan & 4 & 5.34 & 12 & 16 \\
\hline $\mathbf{6}$ & Less repayment period & 12 & 16 & 23 & 30.67 \\
\hline $\mathbf{7}$ & Inadequate availability of raw materials for IGAs & 8 & 10.67 & 2 & 2.67 \\
\hline $\mathbf{8}$ & There is no proper market for the products & 32 & 42.67 & 27 & 36 \\
\hline $\mathbf{9}$ & Lack of technical guidance & 29 & 38.67 & 22 & 29.33 \\
\hline $\mathbf{1 0}$ & Lack of training and skill development facility & 1 & 1.33 & 2 & 2.67 \\
\hline
\end{tabular}

Table.4

\begin{tabular}{|c|c|c|c|}
\hline Sl. & Suggestions & Frequency & Percentage (\%) \\
No. & Training programmes conducted based on their needs & 120 & 80 \\
\hline $\mathbf{1}$ & To increase the loan and subsidy amount & 110 & 73.33 \\
\hline $\mathbf{2}$ & Unity should be maintained & 85 & 56.67 \\
\hline $\mathbf{3}$ & Follow-up should be increased & 70 & 46.67 \\
\hline $\mathbf{4}$ &
\end{tabular}


Suggestions offered by the beneficiaries to strengthen the performance of self help groups

Suggestions towards improvement of SHGs was showed in Table 21 majority of the respondents $(80 \%)$ suggested that training programmes conducted based on their needs followed by 73.33 per cent members suggested to increase the loan and subsidy amount,56.67 per cent of members suggested that unity should be maintained, 46.67 per cent of members suggested that follow-up should be increased.

The members of SHGs suggested that training programmes should be conducted on a timely seasonally need and demand based trainings. Likewise when the respondents were in need to take up particular enterprise training should be enterprise specific.

Second suggestion was to increase the loan and subsidy amount which will help them in improving the employment opportunities. Some of the members opined that follow-up activities should be conducted on a regular basis. This will enable them to understand their own progress and can make improvements. Another suggestion was unity should be maintained because SHG is a group's activity if any conflicts between members groups do not sustainable for long term.

The findings are in line with Gayathri and Siddaraju (2012)

SHGs helped the women and men to gain economic and social empowerment. It has made the skilled in taking up various activities on their own though the margin of profit was less. Some of the constraints like lack of technical guidance and lack of training and development of skill can be overcome by the policy makers to enhance the formation of
SHGs. Therefore, Government, NGOs and various agencies should come forward to give further guidance to SHGs. The members of SHGs suggested that training programmes should be conducted on a timely seasonally need and demand based trainings. Likewise when the respondents were in need to take up particular enterprise training should be enterprise specific.

There is no doubt that the SHGs had brought about remarkable changes in the lives of members directly and to their family and society indirectly.

\section{References}

Arunkumar Bevenahalli, Chandargi DM (2005). A Critical analysis of SwaShakti programme in Karnataka. M.Sc.(Agri.) Thesis, Univ. Agric. Sci., Dharwad

Bharathi R A, Chhaya Badiger (2005). Assessment of self help Groups promoted under NATP on empowerment of women in Agriculture. M.Sc. Thesis, Univ. Agric. Sci., Dharwad, Karnataka.

Chethana M P (2005). Impact of Stree Shakti programme on farm women in Tumkur district. M.Sc.(Agri) Thesis, Univ. Agric. Sci., Bangalore.

Chitra NN (2011). Impact of 'Kudumbashree' programme on rural women in Kottayam district of Kerala. M.Sc.(Agri) Thesis, Univ. Agric. Sci., Bangalore.

Devalatha C M(2005). Profile study of women SHGs in Gadag district of northKarnataka. M.Sc. (Agri) Thesis, Univ. Agric. Sci., Dharwad, Karnataka.

Gangaiah G, Nagaraja B, Vasudevulu Naidu C (2006). Impact of self-help groups on income and employment: A case study. Kurukshetra, 54 (5):18-23.

Gayathri N K., Siddaraju VG (2012). Women 
empowerment through self help groups in Karnataka- A Case Study In Shimoga District. Asian J. Devt. Matters, 6(1):183-191.

Raghuprasad K P, Umamahesh A B, Mohan I N (2004). Self-help groups: Strengths and constraints in introducing agrobased enterprises. In: National seminar on contemporary challenges for Indian agriculture and rural development, January 2004. UAS, Dharwad.

Sangappa, Narashima N(2012). Performance of gender specific self help groups in Bidar district of Karnataka: comparative analysis. M.Sc. (Agri.) Thesis, Univ. Agric. Sci., Bangalore.

\section{How to cite this article:}

Chinmayi, V. and Basavaraj Beerannavar. 2021. Study on Various Activities in Men and Women Self Help Groups in Shivamogga District, India. Int.J.Curr.Microbiol.App.Sci. 10(04): 316-322. doi: https://doi.org/10.20546/ijcmas.2021.1004.033 